\title{
Peran Interaksi Guru-Siswa dan Gaya Belajar Siswa terhadap Disposisi Berpikir Kritis dalam Pembelajaran Fisika
}

\author{
Primadhani Setyaning Galih ${ }^{1} \mathcal{E}$ Asmadi Alsa ${ }^{2}$ \\ 1,2Fakultas Psikologi Universitas Gadjah Mada
}

\begin{abstract}
This study aimed to empirically determine the role of teacher-student interaction and students' learning styles in students' disposition toward critical thinking in physics subject. Research participants were high school students of grade XI majoring in natural science. Sampling in this study was done using convenience sampling with sample size of 67 students (25 males and 42 females). Data collection method used in this study was survey using Disposition toward Critical Thinking in Physics Subject Scale, Teacher-student Interaction in Physics Subject Scale, and Learning Styles in Physics Subject Scale. Analysis of covariance with one covariate showed 1) there was a correlation between teacher-student interaction and students' disposition toward critical thinking in physics subject $(F=37.199$; $\left.\eta^{2} p=0.375 ; p<0.01\right)$ and 2) there was difference of disposition toward critical thinking in physics subjects between student with diverging, assimilating, accommodating, and converging learning styles $\left(F=6.870 ; \eta^{2} p=0.249 ; p<0.01\right)$. Post-hoc test was also done to further analyze the data. The findings are going to help improving quality of learning especially in the subject being studied by fostering wholesome teacher-student interaction and accommodating students' learning styles.
\end{abstract}

Keywords: analysis of covariance; disposition toward critical thinking; physics subject; students' learning styles; teacher-student interaction

Abstrak. Penelitian ini bertujuan untuk menguji secara empirik peran interaksi guru-siswa dan gaya belajar siswa terhadap disposisi berpikir kritis siswa dalam mata pelajaran fisika. Subjek penelitian adalah siswa kelas XI SMA jurusan Ilmu Pengetahuan Alam (IPA). Sampling pada penelitian ini dilakukan menggunakan convenience sampling dengan besar sampel 67 siswa (25 laki-laki dan 42 perempuan). Metode pengumpulan data adalah survei menggunakan Skala Disposisi Berpikir Kritis Siswa dalam Mata Pelajaran Fisika, Skala Interaksi Guru-siswa dalam Mata Pelajaran Fisika, dan Skala Gaya Belajar Siswa dalam Mata Pelajaran Fisika. Hasil analisis kovarian satu kovariat menunjukkan 1) ada korelasi antara interaksi guru-siswa dan disposisi berpikir kritis siswa dalam mata pelajaran fisika ( $F$ $\left.=37,199 ; \eta^{2} p=0,375 ; p<0,01\right)$ dan 2) terdapat perbedaan disposisi berpikir kritis siswa dalam mata pelajaran fisika antara siswa dengan gaya belajar diverging, assimilating, accommodating, dan converging $\left(F=6,870 ; \eta^{2} p=0,249 ; p<0,01\right)$. Uji post-hoc juga dilakukan untuk menganalisis data lebih lanjut. Hasil penelitian bermanfaat untuk meningkatkan kualitas pembelajaran dalam mata pelajaran yang diteliti dengan mendukung interaksi guru-siswa yang baik dan mengakomodasi gaya belajar siswa.

Kata kunci: analisis kovarian; disposisi berpikir kritis; gaya belajar; interaksi guru-siswa; mata pelajaran fisika

${ }^{1}$ Korespondensi mengenai artikel ini dapat dilakukan melalui primadhani.galih@gmail.com

ªtau asmalsa@ugm.ac.id 
Berpikir kritis secara umum tersusun atas komponen keterampilan dan disposisi (Facione, 2015). Komponen-komponen tersebut sudah seharusnya menjadi salah satu luaran yang diharapkan dari sistem pendidikan (Daly, 1998; Molnar, Boninger, \& Fogarty, 2011). Meskipun begitu, pada kenyataannya performansi siswa Indonesia dalam berpikir kritis masih jauh dari memuaskan. Hasil Programme for International Student Assessment (PISA) di bidang matematika, bahasa, dan ilmu pengetahuan alam yang menuntut penggunaan berpikir kritis dalam pengerjaannya menunjukkan bahwa kemampuan siswa Indonesia di tingkat sekolah menengah masih berada di bawah rata-rata (Organisation for Economic Cooperation and Development [OECD], 2016). Hasil asesmen internasional tersebut serta beberapa asesmen lainnya memberikan gambaran bahwa kemungkinan sistem pendidikan di Indonesia belum efektif dalam membentuk generasi siswa yang dapat berpikir kritis.

Ennis (1989) berpendapat bahwa keterampilan dan disposisi berpikir kritis siswa sulit untuk ditransfer dari domain pengetahuan satu ke domain pengetahuan lainnya kecuali dengan instruksi yang eksplisit. Facione, Facione, dan Giancarlo (1997) mendukung pendapat bahwa keterampilan berpikir kritis memang bersifat spesifik pada konteks ilmu tertentu, akan tetapi menyatakan bahwa disposisi berpikir kritis sejatinya merupakan motivasi internal yang konsisten dan tidak terikat pada konteks tersebut. Meskipun hal ini masih menjadi perdebatan para ahli, beberapa studi menyarankan perlunya menggunakan alat ukur yang disusun berdasarkan konteks disiplin dalam mengkaji disposisi berpikir kritis misalnya studi literatur oleh Salsali, Tajvidi, dan Ghiyasvandian (2013) dalam konteks pendidikan keperawatan.
Penelitian ini fokus mengkaji berpikir kritis dalam konteks mata pelajaran ilmu pengetahuan alam. Hal ini dikarenakan pentingnya ilmu pengetahuan alam pada perkembangan perdaban manusia ke depannya. National Research Council (2011) menyatakan bahwa penggerak utama ekonomi masa depan adalah inovasi yang sebagian besar berasal dari perkembangan sains dan teknologi. Karena itu, perilaku berpikir yang baik, ditandai dengan adanya disposisi berpikir kritis siswa, dalam konteks ilmu pengetahuan alam merupakan hal yang krusial.

Pada penelitian ini, peneliti akan fokus pada konteks mata pelajaran fisika. Hal ini dikarenakan masih terbatasnya penelitian yang mengkaji berpikir kritis siswa, khususnya disposisi berpikir kritis siswa, dalam konteks mata pelajaran tersebut kendati pentingnya cabang ilmu fisika. Ilmu fisika sudah sejak lama berkontribusi terhadap kemajuan masyarakat karena fungsinya dalam menjelaskan dan memprediksi fenomena alam (De Wolf, 2003). Meski begitu, banyak siswa merasa kesulitan dalam menguasai konsep-konsep fisika yang diajarkan di kelas (Kurniawati, Wartono, \& Diantoro, 2014). Kesulitan dalam pemahaman dan penguasaan konsep fisika yang merupakan prasyarat individu dalam berpikir kritis tentunya akan menghambat siswa untuk berpikir kritis dalam konteks mata pelajaran fisika.

Perlu dilakukan kajian mengenai faktor-faktor Torres dan Cano (1995) menjelaskan lima kategori faktor yang berperan terhadap perilaku berpikir kritis siswa secara umum yaitu variabel berkaitan dengan guru, variabel berkaitan dengan siswa, karakteristik personal siswa, gaya belajar siswa, dan faktorfaktor yang lain. Variabel yang ditinjau adalah variabel yang terkait dengan guru dan gaya belajar siswa. Variabel-variabel 
yang terkait dengan guru di antaranya adalah keyakinan filosofis, persiapan guru, ekspektasi kognitif, serta pemberian instruksi oleh guru. Gaya belajar yang dimaksud dalam kerangka berpikir ini merupakan preferensi cara belajar siswa.

$$
\text { Proses instruksi diyakini }
$$
pengaruhnya guna mengembangkan kapasitas siswa dalam berbagai domain, salah satunya dalam berpikir kritis (Angeli \& Valanides, 2009; Tsui, 2002). Pendekatan konstruktivisme menekankan satu aspek proses instruksi di kelas yang perlu diperhatikan yaitu interaksi gurusiswa (De Kock, Sleegers, \& Voeten, 2004). Interaksi guru-siswa merupakan sebuah dinamika yang membuat instruksi guru mengenai pelajaran tersampaikan di dalam kelas. Penelitian-penelitian lain juga mendukung pendapat bahwa interaksi guru-siswa yang baik merupakan elemen penting untuk mendorong perkembangan siswa baik dalam domain sosial, perilaku, maupun kognitif di masa kanak-kanak hingga remaja (Battro et al., 2013; Pianta, Belsky, Houts, \& Morrison, 2007).

Styles atau gaya personal individu dalam melakukan pendekatan terhadap tugas-tugas yang dihadapi berbeda antara satu dengan yang lain (Sternberg, Grigorenko, \& Zhang, 2008). Perbedaan ini membentuk cara masing-masing individu dalam berpersepsi, berpikir, dan belajar. Cuthbert (2005) menjelaskan bahwa meskipun siswa dalam satu kelas diberi perlakuan yang sama, mereka dapat menunjukkan hasil belajar yang berbeda satu sama lain dikarenakan gaya belajarnya. Penelitian empiris terhadap siswa berbakat tingkat sekolah menengah di Turki menunjukkan keterkaitan antara aspek-aspek disposisi berpikir kritis siswa dengan gaya belajar siswa (Dilekli, 2017). Temuan Jones, Reichard, dan Mokhtari (2003) pada mahasiswa menunjukkan bahwa setiap orang menunjukkan gaya belajar yang berbeda-beda berdasarkan mata pelajaran yang dihadapi.

Penelitian-penelitian sebelumnya mengindikasikan adanya keterkaitan antara interaksi guru-siswa dan gaya belajar siswa dengan disposisi berpikir kritis siswa. Penelitian yang melihat keterkaitan antara ketiga variabel tersebut belum pernah dilakukan sebelumnya. Selain itu, belum ada penelitian yang mengkaji variabel-variabel tersebut dalam konteks mata pelajaran fisika.

Tujuan utama dari penelitian ini adalah mengkaji peran interaksi gurusiswa dan gaya belajar siswa terhadap disposisi berpikir kritis siswa dalam mata pelajaran fisika. Hipotesis penelitian yang diajukan adalah a) interaksi guru-siswa dalam mata pelajaran fisika berkorelasi dengan disposisi berpikir kritis siswa dalam mata pelajaran fisika, dan b) terdapat perbedaan disposisi berpikir kritis siswa dalam mata pelajaran fisika berdasarkan tipe gaya belajar siswa dalam mata pelajaran fisika. Penelitian ini diharapkan dapat meningkatkan kualitas pembelajaran fisika di dalam kelas.

\section{Metode}

\section{Partisipan}

Penelitian ini mengkaji disposisi berpikir kritis siswa dalam mata pelajaran fisika ditinjau dari interaksi guru-siswa dan gaya belajar siswa. Subjek penelitian adalah siswa kelas XI SMA jurusan IPA yang berjumlah 67 siswa (25 laki-laki dan 42 perempuan). Pemilihan sampel dilakukan dengan menggunakan convenience sampling. Metode penelitian yang digunakan adalah survei, dengan mengumpulkan data subjek menggunakan instrumen pengukuran.

\section{Instrumen}

Skala Disposisi Berpikir Kritis Siswa dalam Mata Pelajaran Fisika. Skala ini 
tersusun atas 20 aitem untuk mengukur variabel disposisi berpikir kritis siswa. Skala ini merupakan hasil modifikasi dari California Measure of Mental Motivation oleh Giancarlo et al. (2004) dan mengukur empat aspek disposisi berpikir kritis remaja, yaitu 1) berpikiran terbuka, 2) regulasi diri, 3) komitmen untuk belajar dan menguasai suatu topik, dan 4) penyelesaian masalah kreatif. Hasil uji coba instrumen menemukan koefisien reliabilitas Cronbach $\alpha=0,933$.

Skala Interaksi Guru-siswa dalam Mata Pelajaran Fisika. Skala ini terdiri atas 28 aitem yang disusun sendiri oleh peneliti berdasarkan model Teaching through Interaction dari Hafen et al. (2015). Model tersebut terdiri atas sebelas komponen yaitu 1) iklim positif, 2) sensitivitas guru, 3) penghargaan terhadap perspektif remaja, 4) iklim negatif, 5) manajemen perilaku, 6) produktivitas, 7) format instruksi pembelajaran, 8) pemahaman konten, 9) analisis dan pertanyaan, 10) kualitas umpan balik, dan 11) dialog instruksi. Lima orang rater yang merupakan dosen
Interaksi Guru-siswa pada Mata Pelajaran Fisika berupa Cronbach $\alpha=0,906$.

\section{Skala Gaya Belajar Siswa dan} Mata Pelajaran Fisika. Skala merupakan hasil modifikasi dari penelitian Mariani (2007) yang terdiri dari empat subskala dan berisi 28 aitem (setiap subskala direpresentasikan oleh 7 aitem). Skala tersebut disusun berdasarkan teori experiential learning dari Kolb (1981) yang menyatakan bahwa proses proses pembelajaran dibagi menjadi empat tahapan atau kuadran dan semuanya dilalui oleh setiap individu yang belajar. Keempat kuadran itu adalah: 1) kuadran perasaan (concrete experience), 2) kuadran pengamatan (reflective observation), 3) kuadran pemikiran (abstract conceptualization), dan 4) kuadran tindakan (active experimentation). Pengelompokkan gaya belajar siswa didasarkan pada dua skor terstandardisasi tertinggi pada kontinum persepsi (kuadran perasaan dan pemikiran) dan kontinum proses (kuadran pengamatan dan tindakan) yang diilustrasikan oleh Tabel 1.

Tabel 1.

Klasifikasi Gaya Belajar Kolb (1981)

\begin{tabular}{ll}
\multicolumn{1}{c}{ Gaya Belajar } & \multicolumn{1}{c}{ Kuadran yang Dominan } \\
\hline Diverging & Perasaan dan pengamatan \\
Assimilating & Pemikiran dan pengamatan \\
Accommodating & Perasaan dan tindakan \\
Converging & Pemikiran dan tindakan \\
\hline
\end{tabular}

psikologi dan lulusan magister psikologi pendidikan menilai validitas konten dari aitem-aitem yang telah dibuat. Analisis Aiken's $V$ menunjukkan bahwa koefisien validitas aitem-aitem berkisar antara 0,65 - 0,85. Peneliti kemudian melakukan uji coba terhadap 90 siswa kelas XI IPA (34 siswa laki-laki dan 56 siswa perempuan). Berdasarkan hasil uji coba alat ukur ditemukan koefisien reliabilitas Skala
Exploratory factor analysis dilakukan terhadap skala yang awalnya terdiri dari 40 aitem. Batasan muatan faktor sebesar 0,5 berdasarkan saran Hair, Black, Babin, dan Anderson (2010). Nilai Kaiser-MeyerOlkin's measure of sampling adequacy menunjukkan angka 0,701 dan Bartlett's test of sphericity menunjukkan nilai chisquare 2000,968 dengan taraf signifikansi $p$ $<0,01$ sehingga analisis faktor dapat 
dilakukan (Field, 2013). Mengikuti kriteria Eigenvalue > 1, peneliti mengekstrasi sebelas faktor. Peneliti kemudian melihat scree plot untuk menentukan faktor mana yang layak untuk dipertahankan. Analisis kualitatif kemudian dilakukan guna membuat keputusan mengenai faktor mana yang dapat dipertahankan untuk mempermudah interpretasi faktor (Henson \& Roberts, 2006). Peneliti menggugurkan faktor kelima karena hanya tersusun oleh satu aitem sehingga tersisa empat faktor. Field (2013) menyarankan untuk melakukan analisis ulang dengan membatasi ekstraksi faktor sebanyak empat sesuai dengan jumlah faktor yang telah diputuskan untuk dipertahankan. Peneliti kemudian melakukan analisis faktor kembali dengan membatasi ekstraksi faktor sebanyak empat. Setelah proses tersebut dilakukan, aitem-aitem dengan factor loading terendah pada setiap dimensi digugurkan sehingga setiap dimensi tersusun atas 7 aitem. Berdasarkan hasil uji coba alat ukur terhadap 90 siswa kelas XI IPA (34 siswa guru-siswa (data interval) dan gaya belajar siswa (data nominal) terhadap variabel disposisi berpikir kritis. Uji posthoc dengan teknik penyesuaian Bonferroni juga dilakukan untuk semakin memperdalam analisis.

\section{Hasil}

Variabel disposisi berpikir kritis siswa dalam mata pelajaran fisika menunjukkan $M=56,786$ dan $S D=8,733$. Variabel interaksi guru-siswa dalam mata pelajaran fisika menunjukkan $M=100,514$ dan $S D=13,031$. Peneliti mengkaji rerata dan deviasi standar masing-masing kuadran untuk variabel gaya belajar siswa dalam mata pelajaran fisika: 1) kuadran perasaan $(M=20,014, S D=2,095), 2)$ pengamatan $(M=20,414, S D=1,996), 3)$ pemikiran $(M=18,429, S D=2,171)$, dan 4$)$ tindakan $(M=16,657, S D=2,070)$. Subjek dikategorikan pada tipe-tipe gaya belajar berdasarkan Tabel 1. Tabel 2 menunjukkan distribusi gaya belajar partisipan penelitian.

Tabel 2.

Distribusi Gaya Belajar Siswa dalam Mata Pelajaran Fisika

\begin{tabular}{lcc}
\multicolumn{1}{c}{ Gaya Belajar } & Jumlah Subjek & Persentase \\
\hline Diverging & 22 & $32,84 \%$ \\
Assimilating & 13 & $19,40 \%$ \\
Accommodating & 13 & $19,40 \%$ \\
Converging & 19 & $28,36 \%$ \\
\hline Total & $\mathbf{6 7}$ & $\mathbf{1 0 0} \%$ \\
\hline
\end{tabular}

laki-laki dan 56 siswa perempuan) ditemukan koefisien reliabilitas untuk kuadran perasaan $\alpha=0,875$, kuadran pengamatan $\alpha=0,844$, kuadran pemikiran $\alpha=0,913$, dan kuadran tindakan $\alpha=0,894$.

\section{Analisis data}

Data yang diperoleh dianalisis dengan menggunakan teknik statistik analisis kovarian (ANAKOVA) satu kovariat, untuk menguji peran variabel interaksi

\section{Uji asumsi}

Sebelum melakukan analisis kovarian, peneliti melakukan uji normalitas untuk data yang bersifat interval berdasarkan kelompok gaya belajar (variabel nominal). Hasil tersebut ditunjukkan oleh tabel 3. Peneliti menemukan tiga outlier pada uji normalitas dan menggugurkannya sehingga subjek yang semula berjumlah 70 kemudian menjadi 67 subjek sesuai saran Field (2013). 
Tabel 3.

Hasil Uji Normalitas Kolmogorov-Smirnov Setelah Membuang Outlier

\begin{tabular}{lccccc}
\multicolumn{1}{c}{ Variabel } & Gaya Belajar & Nilai $\boldsymbol{D}$ & Nilai $\boldsymbol{p}$ & Batas $\boldsymbol{p}$ & Keterangan \\
\hline Disposisi & Diverging & 0,146 & 0,200 & $>0,05$ & Normal \\
berpikir kritis & Assimilating & 0,115 & 0,200 & $>0,05$ & Normal \\
siswa & Accommodating & 0,155 & 0,200 & $>0,05$ & Normal \\
& Converging & 0,100 & 0,200 & $>0,05$ & Normal \\
Interaksi guru- & Diverging & 0,144 & 0,200 & $>0,05$ & Normal \\
siswa & Assimilating & 0,117 & 0,200 & $>0,05$ & Normal \\
& Accommodating & 0,177 & 0,200 & $>0,05$ & Normal \\
& Converging & 0,169 & 0,159 & $>0,05$ & Normal \\
\hline
\end{tabular}

Peneliti lalu melakukan uji homogenitas kemiringan garis regresi. Hal ini dilakukan untuk membuktikan bahwatidak ada interaksi antara kovariat dan variabel independen (Field, 2013). Hasil analisis menunjukkan tidak ada interaksi antara kovariat dan variabel independen $(F=1,470 ; p>0,05)$.

Setelah hal tersebut dilakukan maka uji homogenitas varians dapat berjalan. Uji ini dilakukan untuk memastikan bahwa besar varians setiap variabel setara sehingga uji hipotesis dapat dilaksanakan. Uji yang dilakukan dengan Levene's test of error variance. Hasil analisis menunjukkan bahwa varian pada setiap kelompok subjek setara $(F=0,623 ; p>0,05)$.
4 menunjukkan hasil analisis kovarian dengan satu kovariat.

Berdasarkan Tabel 4 ditemukan bahwa interaksi guru-siswa dalam mata pelajaran fisika berkorelasi dengan variabel disposisi berpikir kritis siswa dalam mata pelajaran fisika $\left(F=37,199 ; \eta^{2} p\right.$ $=0,375 ; p<0,01)$. Sebesar 37,5\% varian berpikir kritis dapat dijelaskan oleh variabel interaksi guru-siswa. Selain itu, terdapat perbedaan disposisi berpikir kritis siswa dalam mata pelajaran fisika berdasarkan gaya belajar setelah mengontrol efek kovariat, dengan $(F=$ 6,$\left.870 ; \eta^{2} p=0,249 ; p<0,01\right)$. Gaya belajar siswa berkontribusi terhadap varian berpikir kritis sebesar $24,9 \%$.

Tabel 4.

Hasil Analisis Kovarian Satu Kovariat

\begin{tabular}{lrlrrrr}
\hline $\begin{array}{c}\text { Sumber } \\
\text { Variasi }\end{array}$ & $\begin{array}{r}\text { Jumlah } \\
\text { Kuadrat }\end{array}$ & $d \boldsymbol{b}$ & $\begin{array}{c}\text { Rerata } \\
\text { Kuadrat }\end{array}$ & $\boldsymbol{F}$ & $\boldsymbol{p}$ & $\boldsymbol{\eta}^{2} \boldsymbol{p}$ \\
\hline Corrected Model & 2555,675 & 4 & 638,919 & 18,322 & 0,000 & 0,542 \\
Intercept & 386,494 & 1 & 386,494 & 11,084 & 0,001 & 0,152 \\
Interaksi guru-siswa & 1297,159 & 1 & 1297,159 & 37,199 & 0,000 & 0,375 \\
Gaya belajar siswa & 718,719 & 3 & 239,573 & 6,870 & 0,000 & 0,249 \\
Error & 2161,997 & 62 & 34,871 & & & \\
Total & 219560,000 & 67 & & & & \\
Corrected Total & 4717,672 & 66 & & & & \\
\hline
\end{tabular}

Uji hipotesis

Analisis kovarian dapat dilanjutkan karena semua uji asumsi terpenuhi. Tabel
Tabel 5 menunjukkan rerata nilai disposisi berpikir kritis siswa dalam mata pelajaran fisika berdasarkan gaya belajar setelah mengontrol efek kovariat. Dapat 
Tabel 5.

Mean Skor Disposisi Berpikir Kritis Siswa Berdasarkan Gaya Belajar Siswa

\begin{tabular}{lcc}
\hline \multicolumn{1}{c}{ Gaya Belajar } & Mean & SD \\
\hline Diverging & 52,288 & 1,288 \\
Assimilating & 57,688 & 1,714 \\
Accommodating & 57,041 & 1,639 \\
Converging & 60,641 & 1,357 \\
\hline
\end{tabular}

dilihat bahwa siswa dengan gaya belajar converging memiliki mean skor disposisi berpikir kritis tertinggi, dilanjutkan dengan siswa yang memili gaya belajar assimilating, accommodating, dan terendah adalah diverging.

Hasil uji hipotesis pertama
ditemukan sejalan dengan beberapa
penelitian sebelumnya. Penelitian
Talebinejad dan Matou (2012) dengan
subjek mahasiswa Iran dalam konteks
bahasa Inggris sebagai bahasa asing

Tabel 6 .

Perbandingan Disposisi Berpikir Kritis Siswa berdasarkan Gaya Belajar

\begin{tabular}{lcccl}
\hline Perbandingan Gaya Belajar & MD & Nilai $p$ & Batas $p$ & Keterangan \\
\hline Diverging - Assimilating & 5,400 & 0,103 & $<0,01$ & Tidak signifikan \\
Diverging - Accommodating & 4,753 & 0,160 & $<0,01$ & Tidak signifikan \\
Diverging - Converging & 8,353 & 0,000 & $<0,01$ & Signifikan \\
Assimilating - Accommodating & 0,647 & 1,000 & $<0,01$ & Tidak signifikan \\
Assimilating - Converging & 2,952 & 1,000 & $<0,01$ & Tidak signifikan \\
Accommodating - Converging & 3,600 & 0,577 & $<0,01$ & Tidak signifikan \\
\hline
\end{tabular}

Tabel 6 menunjukkan hasil uji post hoc perbandingan berpasangan dengan menggunakan teknik penyesuaian Bonferroni. Berdasarkan tabel tersebut, perbandingan yang signifikan terjadi antara siswa dengan gaya belajar diverging dan converging.

\section{Diskusi}

Uji hipotesis pertama menunjukkan bahwa interaksi guru-siswa dalam mata pelajaran fisika berkorelasi dengan disposisi berpikir kritis siswa dalam mata pelajaran fisika. Hasil tersebut membuktikan hipotesis pertama penelitian. Variabel ini menjelaskan 37,5\% dari total keseluruhan varian disposisi berpikir kritis siswa dalam mata pelajaran fisika. menunjukkan bahwa interaksi guru-siswa mendorong siswa untuk berpikir kritis. Penelitian tersebut juga menunjukkan ketika guru lebih sering menanyakan informasi eksplisit dari teks, siswa cenderung malas untuk mengkritisi konten implisit dari teks. Penelitian lain oleh Carter dan Rukholm (2008) yang mengaitkan antara interaksi guru-siswa dengan disposisi berpikir siswa kritis dilakukan dalam konteks kelas menulis online bagi mahasiswa keperawatan. Disimpulkan bahwa interaksi guru-siswa yang kuat dan positif meningkatkan disposisi berpikir kritis mahasiswa keperawatan, terutama dalam menulis tulisan ilmiah disiplin ilmunya. Interaksi yang positif dan kuat ditandai oleh asistensi dan perilaku modelling oleh guru.

Interaksi guru-siswa diyakini sebagai inti dari proses pembelajaran di 
dalam kelas. Interaksi guru-siswa menyediakan konteks suportif, afektif, instruksional, dan motivasional guna mendorong perkembangan siswa dalam berbagai domain (Davis, 2003). Kontekskonteks yang menyusun interaksi gurusiswa tersebut salah satunya mendorong perkembangan disposisi berpikir kritis siswa. Jika dilihat melalui konteks instruksional, interaksi guru-siswa menjembatani proses transfer ilmu dari guru ke siswa (Watanabe, 2013). Proses transfer ilmu ini penting karena selain membangun dasar pengetahuan dan keterampilan yang kuat (van Gelder, 2005), juga mengembangkan karakteristik siswa yang sesuai dengan target pendidikan (McCune \& Entwistle, 2011).

Konteks suportif seperti dukungan dan motivasi dari guru juga ditemukan berperan dalam mengembangkan nilai intrinsik dan usaha belajar siswa remaja di kelas (Dietrich, Dicke, Kracke, \& Noack, 2015). Nilai intrinsik dan usaha belajar siswa terkait dengan konsep disposisi berpikir kritis yang dikaji dalam penelitian ini. Proses belajar yang didorong oleh nilai intrinsik dilakukan karena siswa menikmati proses belajar tersebut, bukan karena menginginkan faktor eksternal seperti nilai atau pujian. Hal ini sejalan dengan aspek disposisi berpikir kritis yang digunakan dalam penelitian ini, terutama berpikir terbuka dan komitmen untuk belajar dan menguasai topik (Giancarlo, Blohm, \& Urdan, 2004). Sementara itu siswa dengan tingkat usaha belajar yang tinggi dinilai dapat menyelesaikan tugas dengan disiplin dan tahan dalam menghadapi tantangan belajar (Dietrich et al., 2015). Hal ini sesuai dengan aspek disposisi berpikir kritis regulasi diri dan komitmen untuk menguasai suatu topik.

Proses pengembangan disposisi berpikir kritis siswa melalui kontekskonteks interaksi guru-siswa dapat diilustrasikan dengan proses scaffolding. Scaffolding merupakan interaksi dinamis ketika guru membimbing siswa sesuai dengan kondisi siswa (kemampuan dan tanggapan siswa terhadap bimbingan guru) dan secara progresif menyerahkan tanggung jawab belajar kepada siswa agar ia menjadi independen (van de Pol, Volman, \& Beishuizen, 2010). Scaffolding dalam mata pelajaran fisika dapat dilakukan guru dengan memberikan pertanyaan yang menstimulasi, saran, petunjuk, dan sebagainya berkaitan dengan topik fisika yang dibahas (Etkina, 2010). Scaffolding dilakukan dalam zone of proximal development (ZPD) atau zona kesenjangan antara tugas yang dikuasai siswa dengan mandiri dan yang belum dikuasai siswa. Zona ini merupakan area yang krusial guna mengarahkan siswa untuk mengembangkan disposisi berpikir kritis (Wass \& Golding, 2014).

Guru fisika dan pihak sekolah masih memiliki ruang untuk meningkatkan kualitas interaksi guru-siswa dalam mata pelajaran fisika di kelas, terutama pada subjek-subjek yang berada pada kategori sangat rendah. Peningkatan kualitas interaksi guru-siswa dalam mata pelajaran fisika pada siswa tersebut jika dikaitkan dengan hasil uji hipotesis pertama diharapkan dapat meningkatkan disposisi siswa untuk berpikir kritis dalam mata pelajaran fisika.

Uji hipotesis yang kedua menunjukkan perbedaan disposisi berpikir kritis siswa dalam mata pelajaran fisika berdasarkan gaya belajar siswa dalam mata pelajaran fisika. Gaya belajar siswa dalam mata pelajaran siswa disimpulkan berkontribusi sebanyak 24,9\% terhadap disposisi berpikir kritis siswa dalam mata pelajaran fisika setelah mengontrol efek dari kovariat atau variabel interaksi guru-siswa dalam mata pelajaran fisika. 
Hasil ini sejalan dengan hasil dari beberapa penelitian sebelumnya dalam konteks pendidikan yang lain. Kajian literatur oleh Andreou, Papastavrou, dan Merkouris (2014) dalam konteks pendidikan keperawatan menyimpulkan bahwa gaya belajar siswa merupakan salah satu determinan keterampilan dan disposisi berpikir kritis. Penelitian lain oleh Dilekli (2017) terhadap siswa berbakat tingkat pendidikan sekolah menengah juga menemukan bahwa setiap gaya belajar menunjukkan disposisi dan keterampilan berpikir kritis yang berbeda.

Pada praktiknya, siswa dalam satu kelas menjalani proses pembelajaran bersama akan tetapi mereka menunjukkan hasil belajar yang berbeda-beda. Selain dikarenakan kapasitas kognitif siswa, Cuthbert (2005) menjelaskan jika gaya belajar masing-masing siswa berpengaruh terhadap hasil tersebut. Gaya merupakan perbedaan individu dalam melakukan pendekatan terhadap tugas-tugas yang dihadapi (Sternberg et al., 2008). Pada konteks penelitian ini gaya belajar yang digunakan merupakan konsep gaya belajar Kolb (Kolb \& Kolb, 2009) yang didasari oleh cara individu mengolah informasi.

Pithers (2002) menyatakan bahwa gaya belajar membentuk cara individu berpersepsi, berpikir, menyelesaikan masalah, dan belajar. Hal tersebut berkaitan dengan konsep disposisi berpikir kritis yang digunakan dalam penelitian ini. Giancarlo et al. (2004) menyebutkan penyelesaian masalah kreatif sebagai salah satu aspek dari berpikir kritis. Ditemukan bahwa gaya belajar individual mempengaruhi individu dalam melakukan pendekatan, proses penyelesaian, dan hasil dari penyelesaian masalah (Treffinger, Selby, \& Isaksen, 2008). Penelitian lain oleh Zhang (2003) juga menunjukkan bahwa gaya belajar siswa berkaitan dengan beberapa aspek disposisi berpikir kritis seperti regulasi diri, rasa ingin tahu, dan komitmen untuk menguasai suatu topik.

Hasil uji post hoc menunjukkan perbedaan disposisi berpikir kritis siswa dalam mata pelajaran fisika yang signifikan antara siswa dengan gaya belajar diverging dan converging $(M D=$ 8,353, $\quad p<0,01)$. Perbandingan berpasangan gaya-gaya belajar lainnya tidak menunjukkan hasil signifikan $(p>$ 0,05). Skor disposisi berpikir kritis siswa dalam mata pelajaran fisika tertinggi ditunjukkan oleh siswa dengan gaya belajar converging, dilanjutkan dengan gaya belajar assimilating, lalu gaya belajar accommodating, dan terakhir adalah gaya belajar diverging.

Sejalan dengan hasil ini, An dan Yoo (2008) juga menemukan hubungan yang kuat antara gaya belajar converging dengan disposisi berpikir kritis siswa. Hal ini dikarenakan siswa yang dominan dalam kuadran pemikiran (abstract conceptualization) dan tindakan (active experimentation) lebih cenderung menerapkan kapasitas berpikir kritis guna mengolah informasi baru. Kapasitas berpikir kritis yang dimaksud adalah kecenderungan untuk melakukan organisasi pikiran yang rapi, penalaran, dan usaha untuk memprediksi hasil dari suatu situasi (An \& Yoo, 2008).

Penelitian terhadap siswa berbakat dengan tingkat pendidikan sekolah menengah di Turki juga menunjukkan hasil yang sama (Dilekli, 2017). Selain menunjukkan bahwa tipe gaya belajar siswa berkorelasi dengan keterampilan dan disposisi berpikir kritisnya. Dilekli (2017) juga menemukan bahwa siswa dengan gaya belajar converging dan assimilating menunjukkan kapasitas berpikir kritis yang lebih tinggi daripada siswa dengan gaya belajar yang lainnya. Analisis lebih lanjut juga menunjukkan bahwa abstract conceptualization 
merupakan prediktor terbesar dari disposisi berpikir kritis siswa (Dilekli, 2017). Keterkaitan abstract conceptualization dengan masing-masing aspek disposisi berpikir kritis juga ditemukan dalam studi Suliman (2006) terhadap mahasiswa keperawatan.

Sebagian besar siswa masih menerapkan gaya belajar diverging yang pada penelitian ini menunjukkan rerata disposisi berpikir kritis terendah dibandingkan dengan gaya belajar yang lain. Berdasarkan hasil uji hipotesis kedua dan analisis tambahan, ada baiknya jika guru fisika dan pihak sekolah menekankan tahapan belajar abstract conceptualization dan active experimentation yang merupakan karakteristik gaya belajar converging (Kolb, 1981). Hal ini dilakukan untuk mendorong perkembangan disposisi berpikir kritis siswa, terutama dalam konteks mata pelajaran fisika.

Mata pelajaran eksakta seperti fisika merupakan mata pelajaran yang kompleks karena menuntut individu untuk melakukan abstraksi suatu fenomena nyata ke dalam bentuk matematis dan juga menghubungkan berbagai konsep fisika dengan tepat agar dapat diaplikasikan ke dalam kasus baru (McDermott, 2001). Memiliki ketertarikan untuk memanipulasi simbol-simbol abstrak, kecenderungan berpikir sistematis, serta analisis kuantitatif yang baik yang merupakan deskripsi dari abstract conceptualization (Kolb \& Kolb, 2009) mendukung individu untuk berpikir kritis dalam mata pelajaran fisika. Ketertarikan untuk memanipulasi simbol abstrak dan analisis kuantitatif diperlukan karena dalam mata pelajaran fisika siswa dituntut untuk melakukan perhitungan matematis dengan simbol-simbol yang melambangkan konsep fisika. Kecenderungan untuk berpikir secara sistematis pun diperlukan agar siswa dapat melakukan penyelesaian masalah fisika dengan runtut dan membangun argumen yang koheren.

Tahapan active experimentation selalu ditekankan oleh sebagian besar guru fisika di seluruh dunia, salah satunya dengan mendorong siswa untuk melakukan percobaan-percobaan untuk menguji fenomena fisika (Etkina, van Heuvelen, Brookes, \& Mills, 2002). Siswa diminta untuk mencoba melakukan percobaan secara langsung. Penelitian Bigozzi, Tarchi, Fiorentini, Falsini, dan Stefanelli (2018) menemukan bahwa proses percobaan ini memiliki andil besar dalam perkembangan kapasitas berpikir kritis siswa dan pemahaman siswa akan konsep keilmuan dalam konteks belajar fisika. Akan tetapi guru perlu mendampingi proses ini dengan interaksi guru-siswa yang konstruktif, yaitu dengan menstimulasi keingintahuan siswa dan meminta mereka untuk memprediksi mengenai hasil percobaan yang akan dilakukan (Bigozzi et al., 2018).

Terdapat beberapa keterbatasan di dalam penelitian ini. Peneliti melakukan spesifikasi konteks pada mata pelajaran fisika ketika mengkaji disposisi berpikir kritis siswa meskipun belum didukung oleh dasar teoretis yang kuat. Hal ini berlanjut pada operasionalisasi variabel dan proses modifikasi instrumen penelitian oleh peneliti. Kurang tepatnya operasionalisasi variabel dan modifikasi instrumen penelitian dapat menimbulkan bias yaitu variabel yang terukur tidak sesuai dengan konstruk teoretis yang digunakan (Polit \& Benk, 2010). Meskipun begitu, hasil penelitian ini mampu memberikan dasar bagi penelitianpenelitian dengan topik yang sama di masa depan untuk lebih berhati-hati terhadap pengerucutan konteks penelitian.

Selain itu, konstruk berpikir kritis siswa dalam mata pelajaran fisika yang 
diukur dalam penelitian ini hanya mencakup disposisi berpikir kritis siswa. Konsep berpikir kritis oleh Facione (2015) yang merupakan dasar dari dasar teori yang digunakan dalam penelitian ini menjelaskan bahwa berpikir kritis merupakan gabungan antara keterampilan dan disposisi. Aktivitas berpikir kritis yang idealnya dapat dilakukan siswa, merupakan manifestasi dari keterampilan individu untuk berpikir kritis yang didorong oleh disposisi atau kecenderungannya untuk berpikir kritis (Facione, Facione, \& Giancarlo, 2000). Gambaran berpikir kritis siswa dalam mata pelajaran fisika pada penelitian ini belum menyeluruh karena tidak mengikutsertakan dimensi keterampilan siswa untuk berpikir kritis dalam mata pelajaran fisika.

\section{Kesimpulan}

Interaksi guru-siswa dan gaya belajar siswa ditemukan berperan terhadap disposisi berpikir kritis siswa dalam mata pelajaran fisika. Hal ini ditunjukkan oleh korelasi antara variabel interaksi gurusiswa dengan disposisi berpikir kritis siswa dalam mata pelajaran fisika. Setiap kelompok gaya belajar juga menunjukkan perbedaan skor disposisi berpikir kritis dalam mata pelajaran fisika.

Faktor eksternal (interaksi gurusiswa) dan internal (gaya belajar siswa) berperan terhadap perkembangan disposisi berpikir kritis siswa dalam mata pelajaran fisika. Analisis menunjukkan bahwa ukuran efek interaksi guru-siswa lebih besar dibandingkan gaya belajar siswa. Hal tersebut menunjukkan bahwa interaksi siswa dengan guru di dalam kelas berperan lebih besar terhadap disposisi berpikir kritis siswa dibandingkan dengan gaya belajar siswa, terutama dalam konteks mata pelajaran fisika. Guru memiliki banyak ruang untuk mengembangkan disposisi berpikir kritis siswa. Usaha untuk meningkatkan kualitas interaksi dengan siswa di kelas perlu dilakukan terus-menerus.

Meskipun begitu, tidak ada salahnya apabila guru memberikan stimulasi agar siswa mampu mengembangkan gaya belajar converging. Hal ini berarti bahwa guru tetap perlu menekankan pentingnya tahapan abstract conceptualization dan active experimentation dalam proses pembelajaran fisika.

\section{Saran}

Belum ada dasar teori kuat yang mendukung spesifikasi disposisi berpikir kritis berdasarkan mata pelajaran tertentu. Oleh karena itu, penelitian selanjutnya diharapkan meneliti konsep disposisi berpikir kritis dalam konteks yang lebih luas, tidak hanya terbatas pada mata pelajaran ini saja. Selain itu ada baiknya untuk sekaligus mengkaji keterampilan berpikir kritis siswa guna mendapatkan gambaran yang lebih komprehensif mengenai kapasitas berpikir kritis siswa Indonesia pada penelitian berikutnya.

\section{Kepustakaan}

An, G. J., \& Yoo, M. S. (2008). Critical thinking and learning styles of nursing students at the baccalaureate nursing program in Korea. Contemporary Nurse, 29(1), 100-109.

Andreou, C., Papastavrou, E., \& Merkouris, A. (2014). Learning styles and critical thinking relationship in baccalaureate nursing education: A systematic review. Nurse Education Today, 34(3), 362-371.

doi: 10.1016/j.nedt.2013.06.004

Angeli, C., \& Valanides, N. (2009). Instructional effects on critical thinking: Performance on ill-defined 
issues. Learning and Instruction, 19(4), 322-334. doi: 10.1016/j.learninstruc.2008.06.010

Battro, A. M., Calero, C. I., Goldin, A. P., Holper, L., Pezzatti, L., Shalóm, Diego, E., Sigman, M. (2013). The cognitive neuroscience of the teacher-student interaction. Mind, Brain, and Education, 7(3), 177-181. doi: $10.1111 / \mathrm{mbe} .12025$

Bigozzi, L., Tarchi, C., Fiorentini, C., Falsini, P., \& Stefanelli, F. (2018). The influence of teaching approach on students' conceptual learning in physics. Frontiers in Psychology, 9, 114. doi: $10.3389 \% 2 F f p s y g .2018 .02474$

Carter, L. M., \& Rukholm, E. (2008). A study of critical thinking, teacherstudent interaction, and disciplinespecific writing in an online educational setting for registered nurses. Journal of Continuing Education in Nursing, 39(3), 133-138.

Cuthbert, P. F. (2005). The student learning process: Learning styles or learning approaches. Teaching in Higher Education, 10(2), 235-249. doi: $\underline{10.1080 / 1356251042000337972}$

Daly, W. M. (1998). Critical thinking as an outcome of nursing education. What is it? Why is it important to nursing practice? Journal of Advanced Nursing, 28(2), 323-331. doi: 10.1046/j.1365-2648.1998.00783.x

Davis, H. A. (2003). Conceptualizing the role and influence of studentteacher relationships on children's social and cognitive development. Educational Psychologist, 38(4), 207234. doi: 10.1207/S15326985EP3804_2

De Kock, A., Sleegers, P., \& Voeten, M. J. (2004). New learning and the classification of learning environments in secondary education. Review of Educational Research, 74(2), 141-170. doi: $\underline{10.3102 / 00346543074002141}$
De Wolf, E. (2003). The impact of physics on society and the mission of physics education in secondary schools. Europhysics News, 34(3), 98103. doi: $\underline{10.1051 / e p n: 2003305}$

Dietrich, J., Dicke, A.-L., Kracke, B., \& Noack, P. (2015). Teacher support and its influence on students' intrinsic value and effort: Dimensional comparison effects across subjects. Learning and Instruction, 39, 45-54. doi: 10.1016/j.learninstruc.2015.05.007

Dilekli, Y. (2017). The relationships between critical thinking skills and learning styles of gifted students. European Journal of Education Studies, 3(4), 69-96. doi: 10.5281/zenodo.344919

Ennis, R. H. (1989). Critical thinking and subject specificity: Clarification and needed research. Educational Researcher, 18(3), 4-10. doi: 10.3102\%2F0013189X018003004

Etkina, E. (2010). Pedagogical content knowledge and preparation of high school physics teachers. Physical Review Special Topics - Physics Education, 6(2), 1-26. doi: 10.1103/PhysRevSTPER.6.020110

Etkina, E. van Heuvelen, A., Brookes, D. T., \& Mills, D. (2002). Role of experiments in physics instruction - a process approach. The Physics Teacher, 40(6), 351-355. doi: $\underline{10.1119 / 1.1511592}$

Facione, P. A. (2015). Critical thinking: What it is and why it counts. Hermosa Beach, CA: Insight Assessment.

Facione, P. A., Facione, N. C., \& Giancarlo, C. A. (1997). The motivation to think in working and learning. In E. A. Jones (Ed.), New directions for higher education (Vol. 96, pp. 67-79). San Fransisco: Jossey-Bass.

Facione, P. A., Facione, N. C., \& Giancarlo, C. A. (2000). The disposition toward 
critical thinking: Its character, measurement, and relationship to critical thinking skill. Informal Logic, 20(1), 61-84. doi: 10.22329/il.v20i1.2254

Field, A. (2013). Discovering statistics using IBM SPSS statistics (Edisi keempat). London: Sage Publications Ltd.

Giancarlo, C. A., Blohm, S. W., \& Urdan, T. (2004). Assessing secondary students' disposition toward critical thinking: Development of the California measure of mental motivation. Educational and Psychological Measurement, 64(2), 347364. doi: 10.1177\%2F0013164403258464

Hafen, C. A., Hamre, B. K., Allen, J. P., Bell, C. A., Gitomer, D. H., \& Pianta, R. C. (2015). Teaching through interactions in secondary school classrooms: Revisiting the factor structure and practical application of the Classroom Assessment Scoring System-Secondary. Journal of Early Adolescence, 35(5-6), 651-680. doi: $\underline{10.1177 \% 2 F 0272431614537117}$

Hair, J. F., Black, W. C., Babin, B. J., \& Anderson, R. E. (2010). Multivariate data analysis (Edisi ketujuh.). Pearson Prentice Hall.

Henson, R. K., \& Roberts, J. K. (2006). Use of exploratory factor common errors and some comment on improved practice. Educational and Psychological Measurement, 66(3), 393416.

doi: 10.1177\%2F0013164405282485

Jones, C., Reichard, C., \& Mokhtari, K. (2003). Are student learning styles discipline specific?. Community College Journal of Research and Practice, 27(5), 363-375. doi: 10.1080/713838162

Kolb. (1981). Learning styles and disciplinary differences. In A. Chickering (Ed.), The Modern
American College: Responding to the new realities of diverse students and a changing society (pp. 232-255). San Fransisco, CA: Jossey-Bass, Inc.

Kolb, A. Y., \& Kolb, D. A. (2009). Experiential learning theory: A dynamic, holistic approach to management learning, education and development. In S. J. Armstrong, \& C. V. Fukami (Eds.), The Sage handbook of management learning, education and development (pp. 42-68). Los Angeles: Sage Publishing.

Kurniawati, I. D., Wartono, \& Diantoro, M. (2014). Pengaruh pembelajaran inkuiri terbimbing integrasi peer instruction terhadap penguasaan konsep dan kemampuan berpikir kritis siswa. Jurnal Pendidikan Fisika Indonesia, 10, 36-46. doi: 10.15294/jpfi.v10i1.3049

Mariani, D. A. (2007). Peran belajar berdasarkan regulasi diri dan gaya belajar terhadap prestasi belajar matematika siswa sekolah menengah atas (Tesis tidak dipublikasikan). Yogyakarta: Universitas Gadjah Mada.

McCune, V., \& Entwistle, N. (2011). Cultivating the disposition to understand in 21st century university education. Learning and Individual Differences, 21(3), 303-310. doi: 10.1016/j.lindif.2010.11.017

McDermott, L. C. (2001). Physics education research: The key to student learning. American Journal of Physics, 69(11), 1127-1137.

Molnar, A., Boninger, F., \& Fogarty, J. (2011). The educational cost of schoolhouse commercialism. Boulder, CO: National Education Policy Center. Diakses melalui http://nepc.colorado.edu/publication Lschoolhouse-commercialism-2011 (pada 22 Januari 2017) 
National Research Council. (2011). Successful K-12 STEM education: Identifying effective approaches in science, technology, engineering, and mathematics. Washington, DC: National Academic Press.

Organisation for Economic Co-operation and Development (OECD). (2016). PISA 2015: Results in focus. OECD.

Pianta, R. C., Belsky, J., Houts, R., \& Morrison, F. (2007). Opportunities to learn in America's elementary classrooms. Science, 315, 1795-1796. doi: $10.1126 /$ science.1139719

Pithers, R. T. (2002). Cognitive learning Style: A review of the field dependent-field independent approach. Journal of Vocational Education \& Training, 54(1), 117-132. doi: $10.1080 / 13636820200200191$

Polit, D. F., \& Benk, C. T. (2010). Essentials of nursing research: Appraising evidence for nursing practice (Edisi ketujuh). Philadelphia: Lippincott Williams \& Wilkins.

Salsali, M., Tajvidi, M., \& Ghiyasvandian, S. (2013). Critical thinking dispositions of nursing students in Asian and non-Asian countries: A literature review. Global Journal of Health Science, 5(6), 172-178. doi: 10.5539/gjhs.v5n6p172

Sternberg, R. J., Grigorenko, E. L., \& Zhang, L. F. (2008). Styles of learning and thinking matter in instruction and assessment. Perspectives on Psychological Science, 3(6), 486-506. doi: 10.5539/gjhs.v5n6p172

Suliman, W. A. (2006). Critical thinking and learning styles of students in conventional and accelerated programmes. International Nursing Review, 53(1), 73-79. doi: 10.1111/j.1466-7657.2006.00445.x

Talebinejad, M. R., \& Matou, Z. (2012). Teacher-student interaction in EFL reading comprehension contexts at university level: A critical thinking perspective. SAGE Open, 1-16. doi: 10.1177/2158244012459335

Torres, R. M., \& Cano, J. (1995). Critical thinking as influenced by learning style. Journal of Agricultural Education, 36(4), 55-62.

Treffinger, D. J., Selby, E. C., \& Isaksen, S. G. (2008). Understanding individual problem-solving style: A key to learning and applying creative problem solving. Learning and Individual Differences, 18(4), 390-401. doi: 10.1016/j.lindif.2007.11.007

Tsui, L. (2002). Fostering critical thinking through effective pedagogy: Evidence from four institutional case studies. The Journal of Higher Education, 73(6), 740-763. doi: $\underline{10.1080 / 00221546.2002 .11777179}$

van de Pol, J., Volman, M., \& Beishuizen, J. (2010). Scaffolding in teacherstudent interaction: A decade of research. Educational Psychology Review, 22(3), 271-296. doi: 10.1007/s10648-010-9127-6

van Gelder, T. (2005). Teaching critical thinking: Some lessons from cognitive science. College Teaching, 53(1), 41-46.

Wass, R., \& Golding, C. (2014). Sharpening a tool for teaching: The zone of proximal development. Teaching in Higher Education, 19(6), 671-684. doi: $\underline{10.1080 / 13562517.2014 .901958}$

Watanabe, K. (2013). Teaching as a dynamic phenomenon with interpersonal interactions. Mind, Brain, and Education, 7(2), 91-100. doi: 10.1080/13562517.2014.901958

Zhang, L. F. (2003). Contributions of thinking styles to critical thinking dispositions. The Journal of Psychology: Interdisciplinary and 
INTERAKSI GURU SISWA, GAYA BELAJAR, DISPOSISI BERPIKIR KRITIS, FISIKA

Applied, 137(6), 517-544. doi: 